\title{
Social Factors: Women and Cancer
}

\author{
Jeanne Mager Stellman and Steven D. Stellman
}

\begin{abstract}
Numerous factors in the social environment may affect the incidence and mortality from cancer in women. Women's work roles, possible exposure to workplace hazards, social class, social roles, social stress, access to health care, and health behaviors are among the factors that act together to help determine a woman's health and well-being.

Copyright (C) 1995 by W.B. Saunders Company
\end{abstract}

A WOMAN'S personal physiological make-up, her lifetime of exposures to various environmental conditions, the social roles she assumes, and her overall economic circumstances are among the factors that act together to help determine her health and well-being. For some of these factors, such as exposure to carcinogens on the job or cigarette smoking, the relationship to cancer causation is well established. For other factors, predominantly socioeconomic status, the evidence points more to social, rather than biologic, "causation" of disease. And for those factors related to psychosocial "stress," neither a direct chain of causation, nor any plausible biological mechanism, has as yet been established that directly links them to cancer causation itself; although, as discussed below, the presence of social support networks may lower cancer mortality.

This article discusses factors in the social environment that may affect the incidence of and mortality from cancer in women. The data presented focus on factors relating to women's work roles, both paid and unpaid, to issues of access to the health care system, and to possible exposure to workplace hazards associated with cancer risks.

\section{OCCUPATIONAL EXPOSURES TO TOXIC CONDITIONS}

Chemical and physical hazards can be encountered in a wide variety of occupations and industries. More than 10,000 chemicals are routinely used in commerce. Unfortunately, no complete inventory of the degree of worker exposure to chemicals exists. By examining the data available in the National Library of Medicine's Hazardous Substances Data Base, which lists industrial uses of chemicals, and by comparing these data to the known or suspected human carcinogens lists, compiled and published by the International Agency for Research on Cancer, IARC, ${ }^{1}$ a list of industries with substantial female employment and with potential exposures to these IARC carcinogens has been developed ${ }^{2}$ and is partially presented in Table 1 .

Several industries with potential exposures for women are particularly notable in this list. The health care industry is both the largest employer in the United States and also a heavily femaledominated industry. Women workers can be exposed to several carcinogens during the course of their work in health care. For example, nurses who administer cancer chemotherapeutic drugs are themselves exposed to the aerosols generated during drug administration, unless careful precautions are taken. Patients who have been dosed with radioactive isotopes may themselves emit radiation. Patient waste products can also be radioactive, as can bedlinens and clothing. Health care workers will be exposed to the radiation unless adequate shielding methods have been used. A number of commonly used sterilizing agents, such as ethylene oxide, are associated with cancer. Hepatitis B, an occupational hazard for health care workers, is a risk factor for the development of liver cancer. Formaldehyde, which is widely used in clinical laboratories, is a human carcinogen. ${ }^{3}$

In the manufacturing sector, the textile industry, another heavily female-dominated industry, has a number of possible carcinogenic exposures, including the formaldehyde found in permanent press finishes and some of the textile dyes. In some

From the School of Public Health, Columbia University, New York, NY, and the Division of Epidemiology, American Health Foundation, New York, N.Y.

Jeanne Mager Stellman, PhD: Associate Prfessor, School of Public Health, Columbia University; Steven D. Stellman, PhD, MPH: Chief, Division of Epidemiology, American Health Foundation.

Supported in part by NCI Grants No. CA-17613 and CA32617 (S.D.S.).

Address reprint requests to Jeanne Mager Stellman, PhD, School of Public Health, Columbia University, 600 W 168th St, New York, NY 10032.

Copyright (C) 1995 by W.B. Saunders Company

0749-2081/95/1102-0004\$5.00/0 
Table 1. Industries With Substantial Female Employment and With Potential Exposures to IARC-Rated Carcinogens

- Beverage
- Battery manufacture
- Ceramics and pottery
- Cleaning services
- Clinical laboratories
- Clothing and textile
- Cosmetics,
soaps/detergents
- Dental services
- Electrical
- Electronics
- Explosives, ammunition
- Food including dairy and
meat
- Funeral services
- Furniture
- Glass
- Hairdressing and
cosmetology

places, women still continue to sew fireproof protective garments that contain asbestos. Flame retardants are powerful mutagens and may also be related to increased cancer risk. They can be absorbed through the skin of sewing machine operators who handle the treated cloth. Such skin absorption led to the banning of flame retardants in children's sleepwear some years ago for consumers, but no similar worker standards exist.

Other female-intensive industries with potential exposures to mutagenic and/or carcinogenic solvents and other chemicals include the electronics, dry cleaning, small machinery, jewelry making, and some cottage arts and crafts work.

\section{SOCIAL CLASS AND CANCER}

Throughout the industrialized world, social class has repeatedly been found to be strongly related to both the incidence and the mortality of many types of cancer. This relationship has persisted through many decades and holds no matter which of a number of alternative measures of socioeconomic status (SES) has been used. Perhaps the most systematic analyses within a given country have been those of the United Kingdom's Registrar-General, which have reported a nearly twofold relative risk for cancer when comparing most with least disadvantaged. ${ }^{4}$ However, the relation between social class and cancer varies from one cancer site to another, and there are some sites for which the gradient is reversed, such as breast and possibly ovary and kidney.
An important study on this issue was published by Baquet et al in $1991 .^{5}$ Linking data from the SEER Program for three US metropolitan areas between 1978 to 1982 with 1980 data on race, income, and education within individual census tracts, they concluded that the disproportionate distribution of blacks at lower socioeconomic levels accounts for much of their excess cancer burden. For women's cancers, they found opposite SES gradients for breast and cervical cancer, as shown in Table 2. In this study, most black-white differences were statistically significant $(P<.05)$. The trend with education was significant for whites $(P<.01)$ but not blacks. Similar findings were observed using income instead of education.

Although breast cancer is a clear exception to the more general observation that cancer rates tend to be higher in lower SES groups, many studies have shown that survival from breast cancer is strongly and inversely related to SES. For instance, Bassett and Krieger ${ }^{6}$ studied women in whom breast cancer was diagnosed and who were followed up for up to 11 years. They reported a mortality ratio of 1.52 in women from neighborhoods with greater than $35 \%$ working class compared with those with less than $35 \%$, adjusting for race, age, stage, and histological grade. They concluded that in both blacks and whites, poorer social class was a powerful determinant of shortened survival. These results and those of Baquet et $\mathrm{al}^{5}$ indicate that the observed breast cancer survival differences between black and white women in the United States today is substantially caused by the poorer social class standing of blacks.

Cervical cancer, though markedly declining in the United States during the past 40 years, is still a major type of cancer in other parts of the world. In the United States it continues to be a problem in

Table 2. Education, Race, and Cancer Incidence

\begin{tabular}{|c|c|c|c|c|}
\hline & \multicolumn{2}{|c|}{ Cervical Cancer } & \multicolumn{2}{|c|}{ Breast Cancer } \\
\hline & Whites & Blacks & Whites & Blacks \\
\hline $\begin{array}{l}<12 \text { yr } \\
\text { High school }\end{array}$ & 20.2 & 24.4 & 80.2 & 70.3 \\
\hline graduate & 10.4 & 17.1 & 86.7 & 63.8 \\
\hline $\begin{array}{l}\text { Some college } \\
\text { College }\end{array}$ & 6.7 & 19.8 & 98.4 & 79.7 \\
\hline graduate & 3.6 & 4.5 & 116.0 & 77.4 \\
\hline Total & 9.4 & 17.5 & 91.9 & 70.0 \\
\hline
\end{tabular}

NOTE. Age-adjusted incidence, per 100,000.

Data from Baquet et al. ${ }^{5}$ 
immigrant populations. Among Chinese immigrants to New York City, the proportional mortality ratio for cervical cancer is 2.44 times that of United States-born white women, but only $41 \%$ of Chinese women in Tianjin. ${ }^{7}$ This is not a surprising finding when one considers that in many countries, the highest rates of cervical cancer are observed in socially disadvantaged populations. No matter what indicator of SES is used, cervical cancer occurs more commonly in women living in poor countries, those uneducated, and those with low salary. ${ }^{8}$

\section{ACCESS TO HEALTH CARE AND HEALTH BEHAVIORS}

One highly plausible partial explanation of the differences in incidence and mortality found amongst variable social classes is, of course, differential access to and treatment by the health care system. Socioeconomic status has, for example, been shown to be significantly related to compliance with mammography, which in older women is a highly effective method for detecting early breast cancer. ${ }^{9}$ The universality of Pap screening among the higher educated is strongly related to lower cervical cancer incidence, as another example.

Freeman has commented on poverty in relation to race as well as cancer. He points out that "while neither race nor poverty is an absolute indicator of cancer incidence and survival rates, each is a surrogate of predictable conditions and circumstances," and that poverty acts as a "prism of culture," which for the poor may involve smoking, drinking, hazardous occupations, and poor nutrition. ${ }^{10}$

\section{WOMEN'S EARNINGS AND BENEFITS}

Given these impressive data on the relationship of SES to cancer incidence and mortality, it is of interest to note that women in the United States at every occupational level have lower salaries and poorer health and pension benefits than men (Tables 3 and 4). Since one standard way in which socioeconomic status is measured is by using the data given in these tables, it is reasonable to assume that the incidence and mortality of cancer among women will be influenced by them, although the extent to which this occurs is not yet clear.

Despite the fact that there has been substantial change in women's access to a wide variety of occupations, from both legal and social policies perspectives, the majority of women are still employed in a comparatively narrow range of "traditional" occupations and projections into the $21 \mathrm{st}$ century show that this trend will continue. Women are still earning less, on average, than their male counterparts (Table 3). A large percentage of workers receive no medical and pension benefits (Table 4). Among industrial and service workers, women are represented by trade unions to a much lower extent than male workers, although the numbers of unionized men and women have been dropping dramatically.

Because having the financial means for seeking

Table 3. Ratio of Earnings of Women to Earnings of Men According to the Longest Job Held

\begin{tabular}{lcc}
\hline \multicolumn{1}{c}{ Longest Job Held } & $\begin{array}{c}\text { No. of Women: } \\
\text { No. of Men }\end{array}$ & $\begin{array}{c}\text { Ratio of Women to Men } \\
\text { Women's Earnings: } \\
\text { Men's Earnings }\end{array}$ \\
\hline TOTAL & 0.64 & 0.72 \\
Executives, managerial, administrators & 0.62 & 0.64 \\
Professional specialty & 0.80 & 0.71 \\
Technical and related support & 0.81 & 0.78 \\
Sales & 0.58 & 0.57 \\
Administrative support, including clerical & 3.44 & 0.71 \\
Precision product, craft and repair & 0.08 & 0.71 \\
Machine operators, assemblers, and inspectors & 0.56 & 0.66 \\
Transportation and material moving & 0.05 & 0.65 \\
Handlers, equipment cleaners, helpers and laborers & 0.20 & 0.74 \\
Service workers & 0.92 & 0.65 \\
Private household & 20.33 & - \\
Service except private household & 0.88 & 0.66 \\
Farming, forestry and fishing & 0.14 & 0.69 \\
\hline
\end{tabular}

Adapted from Statistical Abstracts of the United States: Table No. 656, 1992.22 
out medical care is one essential component to maintaining health, on average, employed women, who earn far less money than men, will be at a disadvantage. The low levels of coverage of health and pension benefits among workers is striking. Also, it should not be forgotten that even if women are covered by medical plans, these plans often exclude screening examinations, thereby limiting the ability of many women to take these exams and also sending a not-so-subtle message to plan participants that such screening is not a health priority.

\section{SOCIAL STRESS}

Inadequate compensation, unsatisfactory work conditions, and poor benefits coverage can all be thought of as forms of social stress. One definition of social stress is the demands made on an individual by factors in her environment. These demands can be physical, such as exposure to noise or toxic chemicals, or they can be psychological. Time demands are also a form of social stress. In addition to behavioral responses to stress, such as changes in mood or withdrawal from social interactions, the body undergoes a series of biochemical responses to stress, such as increased produc-

Table 4. Percentage of Workers With Pensions and Group Health Plans, 1991

\begin{tabular}{|c|c|c|}
\hline Occupation & $\begin{array}{l}\text { Pension } \\
\%\end{array}$ & $\begin{array}{c}\text { Group } \\
\text { Health } \\
\text { Insurance } \\
\%\end{array}$ \\
\hline TOTAL & 39.5 & 52.3 \\
\hline $\begin{array}{l}\text { Executives, managerial, } \\
\text { administrators }\end{array}$ & 50.8 & 67.4 \\
\hline Professional specialty & 59.4 & 67.5 \\
\hline Technical and related support & 55.0 & 70.1 \\
\hline $\begin{array}{l}\text { Sales } \\
\text { Administrative support }\end{array}$ & 25.3 & 41.2 \\
\hline $\begin{array}{l}\text { including clerical } \\
\text { Precision production, craft and }\end{array}$ & 45.8 & 57.2 \\
\hline $\begin{array}{l}\text { repair } \\
\text { Machine operators, assemblers }\end{array}$ & 41.7 & 58.1 \\
\hline $\begin{array}{l}\text { and inspectors } \\
\text { Transportation and material }\end{array}$ & 43.1 & 63.0 \\
\hline $\begin{array}{l}\text { moving } \\
\text { Handlers, equipment cleaners, }\end{array}$ & 37.5 & 56.1 \\
\hline helpers and laborers & 27.4 & 39.6 \\
\hline Service workers & 21.3 & 29.9 \\
\hline $\begin{array}{l}\text { Private household } \\
\text { Service except private }\end{array}$ & 2.0 & 3.8 \\
\hline household & 22.4 & 31.4 \\
\hline Farming, forestry and fishing & 8.1 & 18.9 \\
\hline
\end{tabular}

Adapted from Statistical Abstracts of the United States: Table No. 661, $1992 .^{22}$ tion of adrenaline. The biochemical responses are in general non-specific, meaning that the physiological response will be the same, regardless of the type of stressor encountered, though, of course, will be elicited to varying degrees.

Although the body does respond to stress with biochemical changes that are measurable in a laboratory, it is still not clear whether any chronic diseases develop as a result of stress. To date there have been no convincing studies demonstrating a positive relationship between social stress and cancer. ${ }^{11}$ Indeed, even though it is widely assumed that diseases like ulcers are "caused" by stress, even here, the empirical data is limited. ${ }^{12}$ The relationship between stress and well-being, on the other hand, is better established. Negative social stress does diminish a person's social effectiveness and can also lead to increased use of cigarettes and other drugs or to poorer eating and exercise habits. Cigarette smoking, use of alcohol, and psychological disorders have been found to be greatly increased among the Vietnam veterans who had been heavily exposed to combat during their tour of duty in Vietnam. ${ }^{13,14}$ Also, as with socioeconomic status, impaired social functioning may decrease the effective use of the health care system for early detection and diagnosis, which, in turn, can increase cancer morbidity and mortality.

In addition, some evidence exists that the extent of social support available to an individual affects mortality, where social support is defined as the resources provided by other persons to an individual. ${ }^{15}$ Social networking, as measured by attendance at religious services and belonging to clubs or groups, has recently been shown to decrease the cancer mortality rate. ${ }^{16}$ Marriage has long been known to have a "protective" effect on mortality, though this effect has been found to be greater for men than for women, and it has not as yet been clearly demonstrated for cancer. Fox has also recently concluded that social support may indeed be the one aspect of social stress that is related to cancer. ${ }^{17}$

\section{MULTIPLE SOCIAL ROLES AND SOCIAL STRESS}

A great deal of attention has been paid to the effect of multiple social roles on the health and well-being of women. There seems to be a growing consensus that multiple roles, such as marriage, participation in the paid workforce, and 
childraising, are health enhancing when those roles are desired and desirable. However, when a woman's social roles are unrewarding and burdensome, perhaps with insufficient financial compensation or social prestige, then multiple roles can have a deleterious effect on health. ${ }^{18}$ The typical modern American woman holds several demanding social roles simultaneously. The majority of adult women are members of the paid work force. In 1991, more than 56 million women were employed outside the home. The majority of these workers were also mothers, many with school-aged children, and more than 5 million with children under the age of 6. Most working mothers are married; however, almost 4 million women were working mothers without a husband present in the household. Thus, it should be assumed that a large number of these women bore the major responsibility for child support. In addition, 3.1 million women were employed in more than one paid job, besides any household and child care responsibilities they may have. Data on the participation of women in the workforce are given in Table 5 and 6 .

Many million women, therefore, occupy at least

Table 5. Distribution in Industry of Women as Workers and Multiple Job Holders, 1991

\begin{tabular}{lrr}
\hline \multicolumn{1}{c}{ Occupation of Primary Job } & $\begin{array}{r}\text { Number } \\
\text { Employed }\end{array}$ & Rate $^{*}$ \\
\hline Managerial, and professional & 14,476 & 6.8 \\
Technical, sales and administrative & & \\
$\quad$ support & 23,418 & 5.8 \\
Precision production, craft and & & \\
$\quad$ repair & 1,096 & 4.0 \\
Machine operators, assemblers and & & \\
inspectors & 4,261 & 4.0 \\
Service workers & 9,282 & 5.8 \\
Farming, forestry and fishing & 594 & 6.6 \\
Agriculture & 728 & 5.6 \\
Wage and salary workers & 49,129 & 6.0 \\
$\quad$ Mining & 145 & 5.8 \\
Construction & 514 & 6.4 \\
Manufacturing & 6,496 & 3.8 \\
$\quad$ Durable goods & 3,107 & 3.9 \\
$\quad$ Nondurable goods & 3,390 & 3.6 \\
$\quad$ Transportation and public utilities & 2,321 & 5.6 \\
Wholesale trade & 1,245 & 5.7 \\
Retail trade & 8,896 & 5.3 \\
Finance, insurance and real estate & 4,206 & 5.4 \\
Services & 22,873 & 7.1 \\
Public administration & 2,434 & 6.2 \\
Self-employed workers & 3,070 & 4.0 \\
Unpaid family workers & 199 & 3.4 \\
\hline
\end{tabular}

* No. of women with multiple jobs as percent of all women in this occupation.

Adapted from Statistical Abstracts of the United States: Table No. $628,1992 .^{22}$ four social roles: paid workers, mothers, homemakers, and wives. To date, definitive research on the relationship of multiple role occupancy to cancer is not available, and such research would require careful design since women with young families are in the age group with very low risk for cancer. The group would be, at best, difficult to study and, at worst, misleading or noninformative as a study population.

No plausible biological arguments have been put forth as to why multiple roles should lead to increased incidence of cancer. Rather, it is conceivable that desired social roles would increase a woman's social support network, and burdensome social roles would decrease her ability to seek out and sustain relationships that might be "protective" against cancer mortality to some extent. These questions are in need of further exploration.

\section{CIGARETTE SMOKING}

Finally, it would be negligent to discuss the relationships between social factors and cancer causation without pointing out that cigarette smoking remains the largest single preventable known cause of cancer. Lung cancer is a leading cause of cancer mortality in women. In the United States, although lung cancer rates in men have exceeded those in women, the rates in women are increasing much faster than in men. During the 15-year period 1970 to 1985 , the rate of squamous cell car-

Table 6. Workforce Participation Rate for Women by Marital Status and Age of Children, 1991

\begin{tabular}{|c|c|c|c|}
\hline \multicolumn{4}{|c|}{ With Children Under 6} \\
\hline Single & & & 48.8 \\
\hline Married & & & 59.9 \\
\hline Widowe & rated & & 59.8 \\
\hline \multicolumn{4}{|c|}{ With Children Age 6-17 } \\
\hline Single & & & 64.8 \\
\hline Married & & & 73.6 \\
\hline Widowe & rated & & 79.5 \\
\hline \multicolumn{4}{|c|}{ Projected Employment in the Female Civilian Population } \\
\hline & Actual & Projected & \\
\hline Age & 1993 & 2005 & \\
\hline $18-19$ & 59.8 & 63.2 & \\
\hline $20-24$ & 70.4 & 75.3 & \\
\hline $25-34$ & 73.3 & 79.7 & \\
\hline $35-44$ & 76.6 & 85.3 & \\
\hline $45-54$ & 72.0 & 81.5 & \\
\hline $55-64$ & 45.3 & 54.3 & \\
\hline $65+$ & 8.6 & 8.8 & \\
\hline
\end{tabular}

Adapted from Statistical Abstracts of the United States: Table No. 620 and 621,1992 . $^{22}$ 
cinoma increased in white men by $25 \%$ and by $156 \%$ in white women, and the rate of adenocarcinoma of the lung increased by $111 \%$ in white men and by $220 \%$ in white women. ${ }^{19}$ This trend is continuing and is largely due to patterns of cigarette smoking, the principal cause of lung cancer, which, in turn, is related to socioeconomic status. A variety of studies have shown that both men and women with less than high school education are more likely to have started smoking cigarettes during childhood and adolescence, ${ }^{20}$ and among younger smokers of both sexes those with at most a high school diploma smoke more cigarettes daily than those with at least some college education. ${ }^{21}$ Prevention of smoking onset in girls as well as boys, along with improved programs of smoking cessation, should be major public health priorities. However, it is obvious that women with multiple roles have fewer opportunities to engage in smoking cessation programs, and that new approaches are needed to reduce this preventable cancer.

\section{CONCLUSION}

Social environmental factors may affect the incidence and mortality from cancer in women. Chemical and physical hazards in the work setting attribute to higher incidences of mutagenic and/or carcinogenic effects in certain occupations. Social class such as lower socioeconomic status increases the relative risk for cancer. One partial explanation for the differences in incidences and mortality found among various social classes is differential access to and treatment by the health care system. Multiple social roles and social stress of women might have a deleterious effect on health. These factors in addition to lifestyle behaviors may contribute to the overall chance of women to develop cancer. Further research is needed to validate the interrelation of the multiple variables on women's risk of cancer.

\section{ACKNOWLEDGMENT}

Steven D. Stellman is supported in part by National Cancer Institute grants CA-17613 and CA-32617.

\section{REFERENCES}

1. International Labor Office: Occupational Cancer: Prevention and Control. Occupational Health Series No. 39. Geneva, Switzerland, 1988

2. Stellman JM: Where women work and the hazards they may face on the job. J Occup Med 36:814-825, 1994

3. Stellman JM: Chemical hazards in hospitals, in Hagberg M, Westlander G (eds): Proceedings of the Pro-Health Care Conference, Stockholm, 1994

4. Logan WPD: Cancer Mortality by Occupation and Social Class, Studies on Medical and Populations Subjects No. 44. London, England, Her Majesty's Stationery Office, 1982

5. Baquet CR, Horm JW, Gibbs T, et al: Socioeconomic factors and cancer incidence among blacks and whites. J Natl Cancer Inst 83:551-557, 1991

6. Bassett MT, Krieger N: Social class and black-white differences in breast cancer survival. Am J Public Health 76:14001403,1986

7. Stellman SD, Wang QS: Cancer mortality in Chinese migrants to New York City: Comparison with Chinese in Tianjin and with white Americans. Cancer 73:1270-1275, 1994

8. de Sanjos S, Bosch X, Mu-oz N: Social differences of sexual behaviour and cancer, in Kogevinas MK, Pearce $N$, Boffetta P, et al (eds): Socioeconomic Factors and Cancer. Lyon, France, IARC (in press)

9. Champion VL: Compliance with guidelines for mammography. Cancer Detect Prev 16:253-258, 1992

10. Freeman HP: Race, poverty, and cancer. J Natl Cancer Inst 83:526-527, 1991

11. Fox BH: Psychosocial factors and the immune system in human cancer, in Ader R (ed): Psychoneuroimmunology. San Diego, CA, Academic, 1981

12. Steptoe A, Fieldman G, Evans O, et al: Psychobiolog- ical stress responses, in Johnston $\mathrm{M}$, Wallace J (eds): Stress and Medical Procedures. Oxford, England, Oxford University Press, 1990

13. Snow B, Stellman JM, Stellman SD, et al: Post traumatic stress disorder in relation to military service in Vietnam among American Legionnaires. Environ Res 47:176-192, 1988

14. Stellman JM, Stellman SD, Sommer JF, Jr: Social and behavioral consequences of combat and herbicide exposure in Vietnam among American Legionnaires. Environ Res 47:129149,1988

15. Cohen S, Syme LS (eds): Social Support and Health. New York, NY, Academic, 1985

16. Stellman JM, Stellman SD, Garfinkel L: Social participation, marital status, caregiving and occupation as predictors of mortality in two-thirds of a million women. Women Health (in press)

17. Fox BH: Job stress and cancer, in Stellman J (ed): ILO Encyclopedia of Occupational Health and Safety. Geneva, Switzerland, International Labor Office (in press)

18. Frankenhaeuer M, Lundberg U, Chesney M (eds): Women, Work and Health: Stress and Opportunities. New York, NY, Plenum, 1991

19. Devesa SS, Shaw GL, Blot WJ: Changing patterns of lung cancer incidence by histological type. Cancer Epidemiol Biomarkers Prev 1:29-34, 1991

20. Escobedo LG, Anda RF, Smith PF, et al: Sociodemographic characteristics of cigarette smoking initiation in the United States. JAMA 264:1550-1555, 1990

21. Wagenknecht LE, Perkins LL, Cutter GR, et al: Cigarette smoking is strongly related to educational status: The CARDIA study. Prev Med 19:158-169, 1990

22. Table No. 656. Statistical Abstracts of the United States (ed 112). Washington, DC, US Bureau of the Census, 1992 